\title{
Suppression of Neuronal Hyperexcitability and Associated Delayed Neuronal Death by Adenoviral Expression of GABA Receptors
}

\author{
Qing Cheng, ${ }^{1}$ John C. Kulli, ${ }^{2}$ and Jay Yang ${ }^{1,2}$ \\ Departments of ${ }^{1}$ Pharmacology and Physiology and ${ }^{2}$ Anesthesiology, University of Rochester Medical Center, Rochester, \\ New York 14642
}

The excessive neuronal excitation underlying several clinically important diseases is often treated with GABA allosteric modulators in an attempt to enhance inhibition. An alternative strategy would be to enhance directly the sensitivity of postsynaptic neurons to GABA. The GABA $\mathrm{C}$ receptor, normally found only in the retina, is more sensitive to GABA and demonstrates little desensitization compared with the $\mathrm{GABA}_{\mathrm{A}}$ receptor. We constructed an adenovirus vector that expressed cDNA for both the GABA $\mathrm{C}_{\mathrm{C}}$ receptor $\rho_{1}$ subunit and a green fluorescent protein (GFP) reporter and used it to transduce cultured hippocampal neurons. Transduced neurons were identified by fluorescence, double immunocytochemistry proved colocalization of the $\rho_{1}$ protein and the reporter, Western blot verified the expected molecular masses, and electrophysiological and pharmacological properties confirmed the presence of functional $G_{A B A}$ receptors. $\rho_{1}$-GFP transduction resulted in an increased density of $\mathrm{GABA}_{A}$ receptors as well as expression of novel $\mathrm{GABA}_{C}$ receptors. This effect was not reproduced by addition of TTX or $\mathrm{Mg}^{2+}$ to the culture medium to reduce action potentials or synaptic activity. In a model of neuronal hyperexcitability induced by chronic blockade of glutamate receptors, expression of $\mathrm{GABA}_{\mathrm{C}}$ receptors abolished the hyperactivity and the consequent delayed neuronal death. Adenovirus-mediated neuronal $\mathrm{GABA}_{\mathrm{C}}$ receptor engineering, via its dual mechanism of inhibition, may offer a way of inhibiting only those hyperexcitable neurons responsible for clinical problems, avoiding the generalized nervous system depression associated with pharmacological therapy.

Key words: $G A B A_{C}$ receptors; hippocampal neurons; adenovirus; hyperexcitability; cell culture; delayed neuronal death
Enhancement of inhibitory neuronal activity may be beneficial for treating CNS diseases characterized by excessive excitation. Experimental models of epilepsy, for example, demonstrate a de-

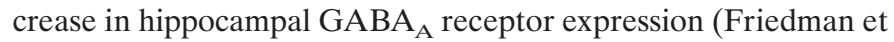
al., 1994; Rice et al., 1996) and function (Gibbs et al., 1997), suggesting that loss of inhibitory control plays a pathogenic role (Mody, 1998). Postischemic and traumatic neuronal death is reduced by the GABA potentiator diazepam (Schwartz et al., 1995; O'Dell et al., 2000). Enhancement of the GABA effect at the receptor is a reasonable strategy for increasing inhibition; this is the mechanism of many clinically useful drugs including anticonvulsants, anxiolytics, and general anesthetics (Hevers and Luddens, 1998). An alternative to receptor modulation is changing the number or type of GABA receptors, with consequent suppression of hyperexcitability. In epilepsy, in which relatively few hyperexcitable neurons are responsible for the initiation of seizures, overexpression of GABA receptors restricted to those few neurons might enhance inhibition with fewer side effects than conventional systemic pharmacotherapy (Jallon, 1997; Loscher, 1998).

The common ionotropic $\mathrm{GABA}_{\mathrm{A}}$ receptor is a pentamer formed of a combination of $\alpha, \beta$, and $\gamma$ subunits. Binding of the ligand GABA opens the integral chloride ion channel, driving the membrane potential toward the chloride equilibrium potential

\footnotetext{
Received Nov. 22, 2000; revised Feb. 6, 2001; accepted March 2, 2001.

This work was supported by National Institutes of Health Grants GM 57578 and GM 52325. We thank Sundeep Malik and Nancy Ward for assistance with molecular constructs.

Correspondence should be addressed to Dr. Jay Yang, Department of Anesthesiology, University of Rochester Medical Centere, 601 Elmwood Avenue, Rochester, NY 14642. E-mail: jay_yang@urmc.rochester.edu.

Copyright (C) 2001 Society for Neuroscience $0270-6474 / 01 / 213419-10 \$ 15.00 / 0$
}

and thus reducing sensitivity to excitatory neurotransmitters. The rarer $\mathrm{GABA}_{\mathrm{C}}$ receptor, another member of the inotropic GABA receptor family, is a homomeric assembly of $\rho_{1}$ subunits (Shimada et al., 1992; Amin and Weiss, 1996); a search for endogenous $\rho$ mRNA using reverse transcription-PCR found $\rho_{1}$ only in bipolar cells of the retina (Boue-Grabot et al., 1998), although other types of $\rho$ subunits are found elsewhere in the CNS (Wang et al., 1994; Enz and Cutting, 1999). Recent evidence that $\rho_{1}$ subunits do not coimmunoprecipitate in vitro with $\alpha_{1}, \alpha_{5}$, or $\beta_{1}$ subunits of $\mathrm{GABA}_{\mathrm{A}}$ suggests that $\rho_{1}$ subunits do not associate with $\mathrm{GABA}_{\mathrm{A}}$ subunits to form receptors (Hackam et al., 1998). Pharmacologically, the $\mathrm{GABA}_{\mathrm{C}}$ receptor is characterized by insensitivity to the $\mathrm{GABA}_{\mathrm{A}}$ antagonist bicuculline and to the $\mathrm{GABA}_{\mathrm{B}}$ agonist baclofen (Bormann and Feigenspan, 1995; Bormann, 2000). Compared with the $\mathrm{GABA}_{\mathrm{A}}$ receptor, the $\mathrm{GABA}_{\mathrm{C}}$ receptor is 40 times as sensitive to GABA, is much slower, requiring eight times as long to activate and deactivate, and shows little or no desensitization (Amin and Weiss, 1994). Because of these favorable properties, forced expression of $\mathrm{GABA}_{\mathrm{C}}$ receptors should significantly enhance the effects of GABA in hyperexcitable neurons.

Adenovirus can transduce hippocampal neurons both in slice and in culture with high efficiency (Wilkemeyer et al., 1996; Griesbeck et al., 1997) and, at least in the short term, without affecting electrical excitability or synaptic transmission (Smith et al., 1997; Lissen et al., 1998; Johns et al., 1999). We report the use, in cultured hippocampal neurons, of a replication-deficient adenovirus designed to express cDNA encoding the $\mathrm{GABA}_{\mathrm{C}}$ receptor $\rho_{1}$ subunit. Overexpression of the $\rho_{1}$ subunit should result in formation of $\mathrm{GABA}_{\mathrm{C}}$ receptors with predictable pharmacological properties and without disruption of the native $\mathrm{GABA}_{\mathrm{A}}$ receptors. 


\section{MATERIALS AND METHODS}

Rat primary hippocampal culture. Sprague Dawley rat pups (1- to 2-d-old) were decapitated, and the hippocampi were dissected out in ice-cold HBSS (Life Technologies, Gaithersburg, MD). The tissue was enzymatically digested with papain and bovine serum albumin (each at $1 \mathrm{mg} / \mathrm{ml}$; Sigma, St. Louis, MO) for $20 \mathrm{~min}$ at $37^{\circ} \mathrm{C}$. Cells were disaggregated by trituration and plated on Matrigel-coated $35 \mathrm{~mm}$ tissue culture plates (Becton Dickinson, Bedford, MA) in Neurobasal medium (Life Technologies) supplemented with $2 \mathrm{~mm}$ L-glutamine, $10 \%$ fetal calf serum (HyClone, Logan, UT), 5\% horse serum, and B-27 supplement (Life Technologies). After $2-3 \mathrm{~d}$ of growth in a $95 \% \mathrm{O}_{2}-5 \% \mathrm{CO}_{2}$ humidified incubator at $37^{\circ} \mathrm{C}$, the dishes were treated with $10 \mu \mathrm{M}$ cytosine arabinoside for $24 \mathrm{hr}$ to suppress the growth of glia. Thereafter, the medium was switched to a Neurobasal medium containing 5\% horse serum and changed every 2-4 d until the cultures were used for experiments.

Induction of neuronal hyperexcitability. Dissociated hippocampal neurons grown with glutamate receptors and synapses chronically blocked $(>14 \mathrm{~d})$ by kynurenate $(1 \mathrm{~mm})$ and magnesium $\left(10 \mathrm{mM} \mathrm{MgCl}_{2}\right)$ became hyperexcitable; when the kynurenate $-\mathrm{Mg}^{2+}$ medium was replaced by a control salt solution without the blockers, neurons displayed seizure-like activity, consisting of bursts of action potentials riding on paroxysmal depolarization shifts (Furshpan and Potter, 1989).

Recombinant adenovirus. The recombinant E1- and E3-deleted replication-deficient human adenovirus type-5 was created via homologous recombination between the pXCR shuttle vector and the pBHG10 parent vector (Bett et al., 1994). So that the $\rho_{1}$ subunit and green fluorescent protein (GFP) proteins would be expressed independently, the shuttle vector was modified to contain two expression cassettes, both driven by the Rous sarcoma virus promoter followed by a multiple cloning site and a polyadenylation sequence. GFP cDNA was subcloned into the first cassette, and human $\rho_{1}$ subunit cDNA (a gift of Dr. Gary Cutting, Johns Hopkins University, Baltimore, MD) was subcloned into the second. The pBHG10 plasmids and the shuttle vector containing the transgene were cotransfected into human embryonic kidney 293 (HEK293) cells using the Ca-phosphate method (Life Technologies). Lytic plaques were isolated and expanded, and the presence of the transgene and the absence of the E1 gene were confirmed by PCR. High-titer adenovirus, twice purified by $\mathrm{CsCl}$ gradient centrifugation, was stored as a $10 \%$ glycerol suspension at $-80 \mathrm{C}^{\circ}$. The titer of each adenovirus preparation was determined by counting GFP-positive plaques formed in a virus-transduced confluent HEK293 monolayer overlaid with low-melt agarose. Because the number of viable cells in a culture dish was unknown, we report the concentration of virus used for transduction of cultured cells as plaque-forming units $(\mathrm{pfu})$ per milliliter rather than as pfu per cell. pBHG10 and pXCR plasmids were purchased from Microbix (Toronto, Ontario, Canada).

Whole-cell recording and data collection. Patch electrodes were pulled from 1.2-mm-outer-diameter borosilicate capillary glass (WPI, Sarasota, FL) and fire polished. The electrodes had a typical resistance of 5-10 $\mathrm{M} \Omega$ when filled with intracellular solution. For voltage-clamp experiments the solution was composed of (in mM): $140 \mathrm{CsCl}, 4 \mathrm{NaCl}, 2 \mathrm{MgCl}_{2}$, $10 \mathrm{~K}$-EGTA, and $10 \mathrm{HEPES}$. For current-clamp recordings of action potentials, $140 \mathrm{~mm}$ K-gluconate replaced CsCl. Solutions were titrated to pH 7.3 with $\mathrm{CsOH}$ or $\mathrm{KOH}$ and supplemented with $2 \mathrm{~mm} \mathrm{Mg-ATP}$. The external solution contained (in $\mathrm{mm}$ ): $140 \mathrm{NaCl}, 2.8 \mathrm{KCl}, 1 \mathrm{MgCl}_{2}, 3$ $\mathrm{CaCl}_{2}, 10$ HEPES, and 10 glucose; the solution was titrated to $\mathrm{pH} 7.4$ with $\mathrm{NaOH}$. Recordings were made using an AxoPatch 200A amplifier (Axon Instruments, Foster City, CA). A typical access resistance of $\sim 15$ $\mathrm{M} \Omega$ in the whole-cell mode of patch clamp was compensated by $75 \%$. Cell input capacitance was approximated by reading the capacitance compensation dial of the amplifier. Recorded membrane currents were filtered at $5 \mathrm{kHz}$, digitized using Clampex v8.0, and analyzed with Clampfit v6.0 (Axon Instruments). Kinetic parameters were determined by simultaneously fitting a monoexponential rising phase (activation) and biexponential decay phase (desensitization) to the evoked current from the beginning to the end of the duration of drug application. A separate monoexponential decay function was fit to the deactivation phase of the current after washout of GABA. A syringe pump delivered external solutions at $15 \mathrm{ml} / \mathrm{hr}$ through orifices of a $\theta$ tube mounted on a piezoelectric transducer (Burleigh Instruments, Fishers, NY). Command steps at $120 \mathrm{sec}$ intervals rapidly moved the perfusion ports, exposing the cell to either the control or the drug solution. The perfusion device allowed exchange of solution in $\sim 15 \mathrm{msec}(10-90 \%$ rise time) for the whole-cell recording configuration. Because of the limited exchange rate, the kinetic parameters determined should be considered approximate and to repre- sent only the upper limit of the true process. For antagonist applications, GABA and the antagonist were applied simultaneously. Because GABA binding to its receptor is rather slow (Jones et al., 1998), rapid equilibrium should be established well within the time scale of tens of milliseconds relevant to our study even without antagonist preexposure. All experiments were performed at room temperature $\left(20-25 \mathrm{C}^{\circ}\right)$; all drugs were purchased from Sigma.

Assay for delayed neuronal death. Unopposed neuronal hyperactivity was induced by replacing the kynurenate $-\mathrm{Mg}^{2+}$ medium in chronically blocked cultures with one without the blockers for a variable time between $15 \mathrm{~min}$ and $24 \mathrm{hr}$. At $24 \mathrm{hr}$ after the initiation of hyperexcitability, delayed neuronal death was determined by ethidium homodimer staining ( $2 \mu \mathrm{M}$ for $5 \mathrm{~min}$ at room temperature). Neuronal injury allows ethidium homodimer to penetrate and intercalate into DNA to yield a bright red fluorescence. The stained culture dishes were examined under an epifluorescence microscope (Olympus IX50), and images of random fields were captured (Dage RC300; Dage-MTI, Michigan City, IN; Scion Imager V3.0; Scion Corporation, Frederick, MD) under both phasecontrast and fluorescent lighting. Phase-contrast images, which do not reveal cell death, were captured first to avoid bias in sampling. Live and dead neurons (100 total) were counted off-line from the captured images to determine the proportion of dead cells.

Immunocytochemistry. Cells grown on glass coverslips were fixed in ice-cold acid methanol (95\% methanol and 5\% acetic acid) for $10 \mathrm{~min}$ and permeabilized in PBS containing $0.2 \%$ Triton X-100 (PBST). The cells were blocked in PBST with $10 \%$ serum for $10 \mathrm{~min}$, and all subsequent reactions were performed in PBST with $2 \%$ serum. Rabbit anti- $\rho_{1}$ polyclonal antibody raised against an epitope of human $\rho_{1}$ peptide conjugated with keyhole limpet hemocyanin (QRQRREVHEDAHK) (Hackam et al., 1997) was prepared and affinity purified by Genemed Synthesis (South San Francisco, CA). Double immunohistochemical staining for GFP and $\rho_{1}$ subunit proteins was accomplished by overnight simultaneous primary antibody exposure [1:200 mouse anti-GFP (Boehringer Mannheim, Indianapolis, IN) and 1:50 rabbit anti- $\rho_{1}$ antibodies] at $4 \mathrm{C}^{\mathrm{O}}$ followed by exposure for $1 \mathrm{hr}$ at room temperature (RT) to antimouse IgG-FITC and anti-rabbit IgG-rhodamine secondary antibody (both at 1:200). Captured images were pseudocolored for the final figures using Adobe Photoshop.

Western blot analysis. HEK293 cells were transduced with the same virus used for neuronal transduction. After $24 \mathrm{hr}$ the majority of the cells were brightly fluorescent but had not yet developed a cytopathic appearance. At this time the cells were scraped off with cold PBS, pelleted, and resuspended in ice-cold lysis buffer $(1 \% \mathrm{NP}-40,50 \mathrm{~mm} \mathrm{NaCl}, 30 \mathrm{~mm} \mathrm{Na}$ pyrophosphate, $30 \mathrm{~mm} \mathrm{NaF}$, and $10 \mathrm{~mm}$ Tris $\mathrm{HCl}, \mathrm{pH}$ 7.6) containing $1 \times$ proteinase inhibitor cocktail (Boehringer Mannheim). After a $30 \mathrm{~min}$ incubation in the lysis buffer on ice and centrifugation at $14,000 \mathrm{rpm}$ for 20 min at $4 \mathrm{C}^{\circ}$, the supernatant was aspirated and quantified for protein and then separated by a $10 \%$ SDS-PAGE. After an overnight transfer onto nitrocellulose and block in 5\% milk in TBS plus Tween (TBST) for $1 \mathrm{hr}$ at RT, paired lanes of control and transfected samples were probed with mouse anti-GFP antibody (1:500) and rabbit anti- $\rho_{1}$ antibody (1:100), all in $2 \%$ milk-TBST, for $2 \mathrm{hr}$ at RT. $\rho 1$-Antibody-specific blocking peptide (25 $\mu \mathrm{g} / \mathrm{ml}$ ) was added to the primary antibody for the blocking peptide experiment. After three washes and a secondary antibody exposure [goat antimouse IgG-HRP (Bio-Rad, Hercules, CA) or cat anti-rabbit IgG-HRP (Santa Cruz Biotechnology, Santa Cruz, CA); both at 1:1000] for $1 \mathrm{hr}$ at RT, the membrane was reacted with a chemiluminescent substrate (NEN Life Sciences, Boston, MA), and an image was obtained by exposing an x-ray film. The final figure was obtained by digitizing the $x$-ray film and composing the images using Adobe Photoshop.

\section{RESULTS}

\section{Recombinant adenovirus expression of GABA $\rho_{1}$ subunits in cultured hippocampal neurons produces functional $\mathrm{GABA}_{\mathrm{C}}$ receptors}

We constructed two recombinant adenoviruses (Ads). The control Ad-GFP expressed only the GFP reporter; the other, Ad- $\rho_{1^{-}}$ GFP, coexpressed both GFP and the $\mathrm{GABA}_{\mathrm{C}} \rho_{1}$ subunit. Hippocampal neuron cultures were transduced with a range of concentrations of the two viruses. After $24 \mathrm{hr}$ at $1 \times 10^{-5} \mathrm{pfu} / 1$ $\mathrm{ml}$, between 10 and $20 \%$ of cells exhibited GFP fluorescence with no apparent effect on the morphology of live neurons (Fig. 1A). 
A

Ad(GFP)
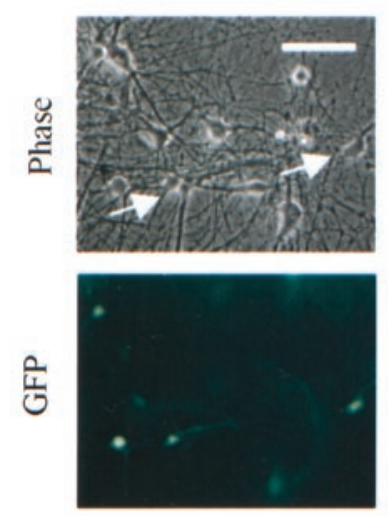

B
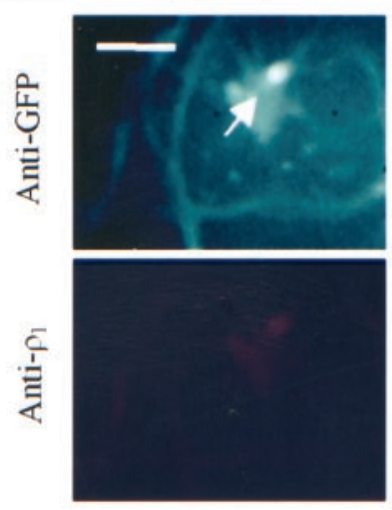

C

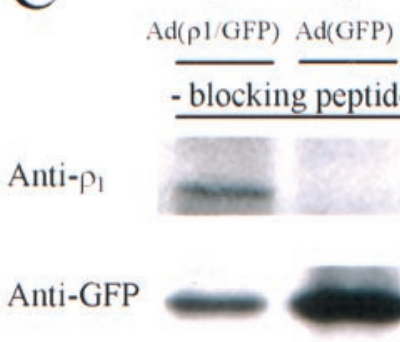

$\operatorname{Ad}\left(\rho_{1} / \mathrm{GFP}\right)$
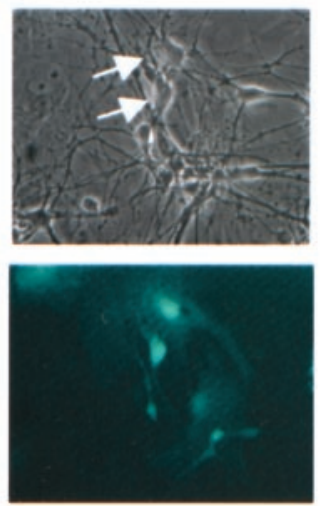

$\underline{\mu M C A C A}$

D

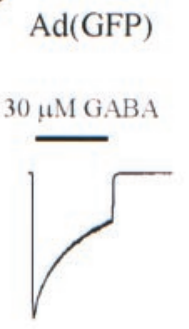

$\operatorname{Ad}\left(\rho_{1} / \mathrm{GFP}\right)$

$30 \mu \mathrm{M} \mathrm{G}$.ABA

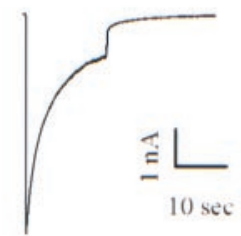

$50 \mu \mathrm{M} \mathrm{CACA}$

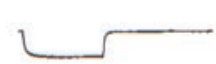

E
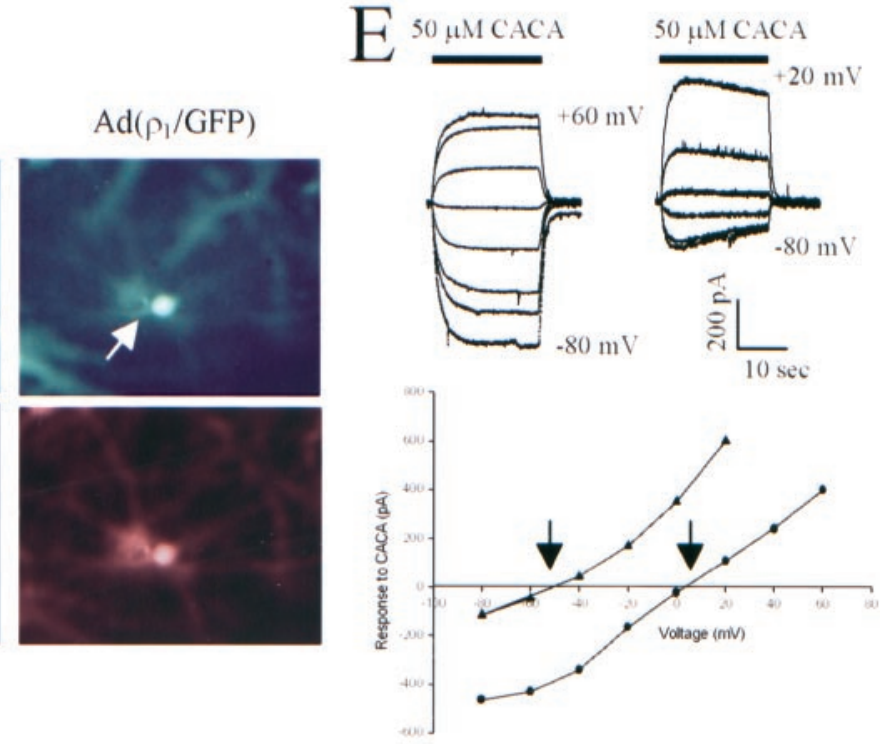

$\operatorname{Ad}(\rho 1 / G F P) \operatorname{Ad}(G F P)$
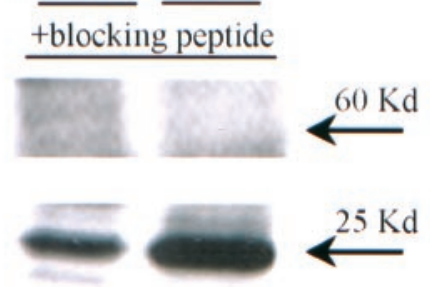

Figure 1. Adenovirus-mediated expression of functional $\mathrm{GABA}_{\mathrm{C}}$ receptors in cultured hippocampal neurons. $A$, Phase-contrast (top) and GFPfluorescent (bottom) image pairs of Ad-GFP-transduced or Ad- $\rho_{1}$-GFP-transduced (both at $1 \times 10^{-5}$ pfu/ml) live cells. GFP-positive cells (examples shown by white arrows) are transduced. $B$, Anti-GFP-antibody-reactive (top) or anti- $\rho_{1}$-antibody-reactive (bottom) fluorescent views of the same field from cultures $48 \mathrm{hr}$ after viral transduction. White arrows point to the virally transduced neurons immunoreactive for GFP. The $\rho_{1}$-GFP-neuron is also immunoreactive to anti- $\rho_{1}$ antibody. $C$, Western blot of detergent-extracted membrane (top) and soluble (bottom) fractions of HEK293 cells transduced with Ad- $\rho_{1}$-GFP (lanes 1, 3) or Ad-GFP (lanes 2, 4). The relative molecular masses are denoted on the right. D, Whole-cell patch-clamp recordings from transduced neurons. The left traces are from GFP-neurons, and the right traces are from $\rho_{1}$-GFP-neurons. $\mathrm{V}_{\mathrm{h}}=-50 \mathrm{mV}$. Drug applications are denoted by the black horizontal bar. E, Current-voltage relationship (bottom graph) obtained from $\rho_{1}$-expressing neurons recorded with high (left) or low (right) intracellular chloride concentrations. Arrows point to the reversal potentials. The expected shift in Nernst chloride potential because of the ionic conditions used was $72 \mathrm{mV}$. Scale bar: $A, B, 150 \mu \mathrm{m}$.

This was the highest concentration at which neurons showed no gross morphological abnormalities and few non-neuronal cells (e.g., glia) were transduced. Double-immunocytochemical staining of Ad- $\rho_{1}$-GFP-transduced neurons ( $\rho_{1}$-GFP-neurons) demon- strates $\rho_{1}$ and GFP immunoreactivity in the same cells (Fig. $1 B$ ). The GFP immunoreactivity is distributed diffusely throughout the cell in both $\rho_{1}$-GFP-neurons and control Ad-GFP-transduced neurons (GFP-neurons). In contrast, $\rho_{1}$ immunoreactivity was 
found only in $\rho_{1}$-GFP-neurons. Comparable $\rho_{1}$ immunoreactivity in dendrites could not be discerned with certainty.

To confirm the expression of proteins of the expected molecular mass, we transduced HEK293 cells with the same viral constructs. Figure $1 C$, a Western blot of the membrane fraction harvested $24 \mathrm{hr}$ after viral transduction, demonstrates an anti- $\rho_{1}$ antibody immunoreactive band at $60 \mathrm{kDa}$ consistent with the expected molecular mass of the $\rho_{1}$ subunit. Identification of this band is confirmed by its disappearance in the presence of a specific anti- $\rho 1$-antibody-epitope blocking peptide. A separate protein band at $25 \mathrm{kDa}$, corresponding to the GFP reporter protein, can also be seen in the soluble fraction; it is not sensitive to the blocking peptide.

Electrophysiological properties of $\rho_{1}$-GFP-neurons, control GFP-neurons, and nonfluorescent neurons were measured by whole-cell patch clamp. Control GFP-neurons were activated by GABA but not by cis-4-aminocrotonic acid (CACA), a GABA $_{C^{-}}$ receptor-selective agonist (Fig. $1 D$ ). In contrast, both GABA and CACA evoked currents in 16 of 17 fluorescent $\rho_{1}$-GFP-neurons. As expected, the CACA-evoked current was kinetically distinct from the GABA-evoked current; activation and deactivation were slow, and there was no significant desensitization. The CACAevoked current in $\rho_{1}$-GFP-neurons demonstrated a linear current-voltage $(I-V)$ relationship with a reversal potential shift $(2.4 \pm 0.7 \mathrm{mV}$ with symmetric chloride concentrations and $-58 \pm$ $1.4 \mathrm{mV}$ with a low internal chloride concentration) consistent with a current carried by the chloride ion (Fig. 1E). These properties are characteristic of current mediated by $\mathrm{GABA}_{\mathrm{C}}$ receptors (Bormann and Feigenspan, 1995). CACA failed to evoke current in nonfluorescent neurons $(n=14)$ from the same culture dish (data not shown). We conclude that $\rho_{1}$-GFP-neurons possess functional $\mathrm{GABA}_{\mathrm{C}}$ receptors.

\section{Kinetic properties of $\mathrm{GABA}_{\mathrm{A}}$ receptors are not modified by expression of $\mathrm{GABA}_{C}$ receptors in the same neuron}

It is possible that the simultaneous expression of both $\mathrm{GABA}_{\mathrm{A}}$ and $\mathrm{GABA}_{\mathrm{C}}$ receptors in the same neuron might alter their kinetic properties. Alternatively, the $\mathrm{GABA}_{\mathrm{A}}$ and $\mathrm{GABA}_{\mathrm{C}}$ receptors may function independently and maintain their respective kinetic properties even when coexpressed together. We examined the time course of GABA-gated currents in transduced neurons. In control neurons, with only $\mathrm{GABA}_{\mathrm{A}}$ receptors, the time course of GABA-gated current was well fit by the expected monoexponential activation, biexponential desensitization, and monoexponential deactivation functions [Figs. 2, left column, top (no virus) and middle (GFP) rows, 3]. GABA-gated current in $\rho_{1}$-GFP-neurons, with both $\mathrm{GABA}_{\mathrm{A}}$ and $\mathrm{GABA}_{\mathrm{C}}$ receptors, is shown in Figure 2 (left column, bottom row). The slower desensitization and deactivation in comparison with those of the $\mathrm{GABA}_{\mathrm{A}}$-only response are readily apparent. The $\mathrm{GABA}_{\mathrm{A}}{ }^{-}$ selective antagonist bicuculline blocked responses to GABA in control neurons and changed the kinetics of the $\rho_{1}$-GFP-neurons to the slowly activating and deactivating current typical of $\mathrm{GABA}_{\mathrm{C}}$ receptors (Fig. 2, middle column). In contrast, the $\mathrm{GABA}_{\mathrm{C}}$-selective antagonist imidazole-4-acetic acid (I4AA) had no effect on control neuron kinetics but returned the kinetics of the $\rho_{1}$-GFP-neurons to that of $\mathrm{GABA}_{\mathrm{A}}$ alone (Fig. 2, right col$u m n)$. Figure 3 shows current traces at expanded time scales to emphasize the kinetic differences between $\mathrm{GABA}_{\mathrm{A}}$ and $\mathrm{GABA}_{\mathrm{C}}$ receptor-gated currents. Currents from nontransduced, GFPneuron, and $\rho 1$-GFP-neuron in the presence of I4AA superim-
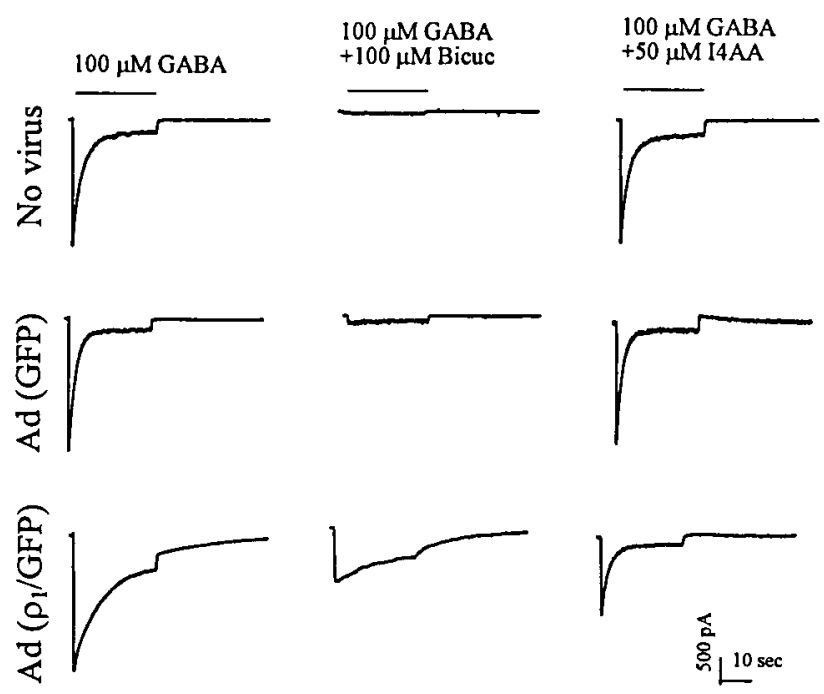

Figure 2. Pharmacological separation of $\mathrm{GABA}_{\mathrm{A}}$ receptor- and $\mathrm{GABA}_{\mathrm{C}}$ receptor-mediated current components. Currents evoked by applications of $100 \mu \mathrm{M}$ GABA alone (left column) or in the presence of $100 \mu \mathrm{M}$ bicuculline (Bicuc; middle column) or $50 \mu \mathrm{m} \mathrm{I4AA} \mathrm{(right} \mathrm{column).} \mathrm{The}$ three drug trials for each row are from the same cell. The representative current records are from neurons not transduced with virus (top row) or transduced with Ad-GFP (middle row) or Ad- $\rho 1-G F P$ (bottom row). The duration of drug application is denoted by the black horizontal lines above the first row of traces.

posed, qualitatively demonstrating no kinetic effect of viral transduction in itself. Current from a $\rho 1-G F P-n e u r o n$ in the presence of bicuculline demonstrated distinct kinetic signatures. Both $\mathrm{GABA}_{\mathrm{A}}$ (Fig. 3D) and $\mathrm{GABA}_{\mathrm{C}}$ (Fig. 3E) receptor-mediated components of $\rho 1$-GFP-neuron were well described by a triexponential activation/desensitization and monoexponential deactivation kinetic model. Parameters of the kinetic fits to the pharmacologically separated currents within the resolution of our limited drug application system are shown in Table 1.

\section{GABA $_{C}$ receptors inhibit hyperexcitable hippocampal neurons}

Ordinarily, hippocampal neurons grown in standard culture conditions exhibit modest levels of spontaneous activity; we observed $0.97 \pm 0.32$ action potentials/sec, as shown in Figure $4 A(n=8)$. Neurons cultured under conditions of chronic kynurenate blockade of glutamate receptors and chronic $\mathrm{Mg}^{2+}$ blockade of synapses were hyperexcitable (Furshpan and Potter, 1989). After removal from chronic blockade, these neurons exhibited spontaneous action potential bursts, typically $300-500 \mathrm{msec}$ long, riding on a wave of depolarization reminiscent of the paroxysmal depolarization shifts seen in epileptic foci in vivo and in vitro (Fig. 4B). The mean action potential rate was $5.5 \pm 1.03 \mathrm{sec}^{-1}$; the rate during bursts approached $20 \mathrm{sec}^{-1}$. This seizure-like electrical hyperexcitability occurred in 11 of 12 neurons examined.

Hyperexcitable neuron cultures were transduced with either Ad- $\rho_{1}$-GFP or the control Ad-GFP. After 2-6 d, whole-cell patchclamp recording was established in neurons expressing GFP. To avoid shifting the chloride reversal potential to a more positive value and thus artifactually enhancing excitability, a low chloride ion internal solution was used. After an initial 1-2 min settling period, action potential firing patterns were stable for at least 20 min for both control and transduced neurons (Fig. 4E). Action potential rates were determined from a 5 min data collection window after stabilization. Typically, control GFP-neurons ex- 


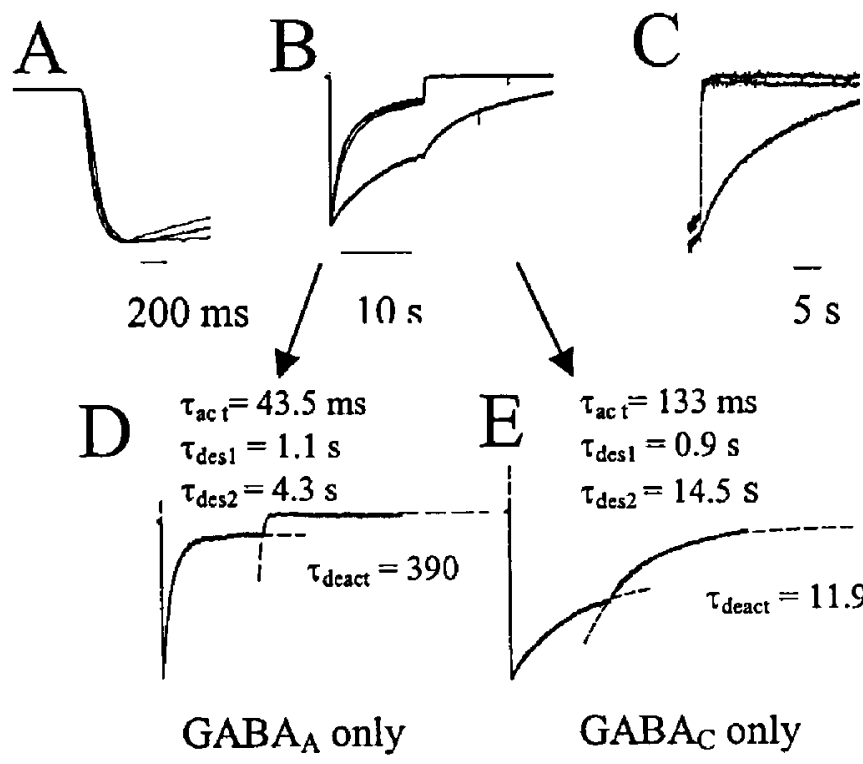

Figure 3. Kinetic properties of GABA-evoked currents in virally transduced hippocampal neurons. $A-C$, GABA $(100 \mu \mathrm{M})$-evoked currents shown at different time resolutions to emphasize the activation $(A)$, desensitization $(B)$, and deactivation $(C)$ phases. The superimposed traces are from nonfluorescent neurons, GFP-neurons, and $\rho_{1}$-GFP-neurons with coapplication of $50 \mu \mathrm{M}$ I4AA or $100 \mu \mathrm{M}$ bicuculline. The peaks of the current traces have been normalized to demonstrate better the kinetic properties of the currents. The kinetically distinct current is from a $\rho_{1}$-GFP-neuron with coapplication of GABA and bicuculline, whereas the remaining three traces superimpose. $D, E$, A kinetic fit of a triexponential $\left(\tau_{\text {act }}, \tau_{\text {des } 1}\right.$, and $\left.\tau_{\text {des } 2}\right)$ function to the activation and desensitization phases and a separate monoexponential $\left(\tau_{\text {deact }}\right)$ function fit to the current deactivation. The two traces are both from $\rho_{1}$-GFP-neurons with GABA coapplied either with I4AA $(D)$ (i.e., the $\mathrm{GABA}_{\mathrm{A}}$ component) or with bicuculline $(E)$ (i.e., the $\mathrm{GABA}_{\mathrm{C}}$ component). See Table 1 for summary of kinetic parameters.

hibited the paroxysmal action potentials characteristic of nontransduced hyperexcitable neurons (Fig. $4 C$ ). In contrast, $\rho_{1}$-GFPneurons exhibited low-frequency spontaneous action potentials without evidence of bursting (Fig. 4D).

Pooled data from several experiments demonstrate large differences in spontaneous action potential rates: nontransduced, $5.4 \pm 1.0 \mathrm{sec}^{-1}$; after Ad-GFP, $5.8 \pm 0.9 \mathrm{sec}^{-1}$; and after Ad- $\rho_{1}$-GFP, $0.48 \pm 0.08 \mathrm{sec}^{-1}$ (Fig. $4 F$ ). The spontaneous action potential frequency of hyperexcitable neurons treated with Ad$\rho_{1}$-GFP was comparable with that of control neurons. Thus Ad$\rho_{1}$-GFP transduction reverses neuronal hyperexcitability in the kynurenate- $\mathrm{Mg}^{2+}$-blockade-induced model of epilepsy.

\section{Both $\mathrm{GABA}_{\mathrm{A}}$ and $\mathrm{GABA}_{\mathrm{C}}$ receptors participate in suppression of hyperexcitability in Ad-o1-GFP- transduced hippocampal neurons}

We then evaluated the effects of selectively activating $\mathrm{GABA}_{\mathrm{A}}$ and $\mathrm{GABA}_{\mathrm{C}}$ receptors in hyperexcitable neurons. Figure $5 \mathrm{~A}$ (left) shows that nontransduced neurons (top), GFP-neurons (middle), and $\rho_{1}$-GFP-neurons (bottom) all responded to GABA $(30 \mu \mathrm{M})$ with membrane hyperpolarization and acute inhibition of spontaneous action potentials. In nontransduced and control neurons, this presumably occurred via activation of constitutively present GABA ${ }_{\mathrm{A}}$ receptors, whereas in $\rho_{1}$-GFP-neurons, GABA activated both $\mathrm{GABA}_{\mathrm{A}}$ and $\mathrm{GABA}_{\mathrm{C}}$ receptors. Figure $5 A$ (right) shows that the $\mathrm{GABA}_{\mathrm{C}}$-selective agonist CACA $(100 \mu \mathrm{M})$ had no effect on nontransduced (top) or GFP-neurons (middle), but in $\rho_{1}$-GFPneurons (bottom), CACA caused membrane hyperpolarization and suppressed action potentials in those few neurons with spontaneous firing.

We also examined the effect of blockade of $\mathrm{GABA}_{\mathrm{A}}$ and GABA $_{\mathrm{C}}$ receptors on $\rho_{1}$-GFP-transduced hyperexcitable neurons. As expected, selective blockade of $\mathrm{GABA}_{\mathrm{A}}$ receptors with bicuculline failed to increase spontaneous firing. Surprisingly, selective blockade of $\mathrm{GABA}_{\mathrm{C}}$ receptors with I4AA also failed to increase spontaneous firing. That is, I4AA did not reverse the suppression of hyperexcitability that followed Ad- $\rho_{1}$-GFP transduction. After coapplication of both bicuculline and I4AA or application of the nonselective GABA receptor antagonist picrotoxin $(50 \mu \mathrm{M})$ alone, blocking both $\mathrm{GABA}_{\mathrm{A}}$ and $\mathrm{GABA}_{\mathrm{C}}$ receptors, the seizure-like electrical activity returned (Fig. $5 B$ ). Thus it appears that Ad- $\rho_{1}$-GFP-induced expression of $\mathrm{GABA}_{\mathrm{C}}$ receptors somehow enhances endogenous $\mathrm{GABA}_{\mathrm{A}}$ receptor-mediated inhibition of neuronal excitability.

To examine further this apparent enhancement of $\mathrm{GABA}_{\mathrm{A}}$ receptor activity, we studied receptor-specific current density after Ad- $\rho_{1}$-GFP transduction. Figure $6 A$ shows GABA-evoked current density (normalized by cell capacitance) from nontransduced neurons (gray bars), GFP-neurons (black bars), and $\rho 1-$ GFP-neurons (hatched bars) at $2 \mathrm{~d}$ intervals after viral transduction. The total current density evoked by $100 \mu \mathrm{M}$ GABA did not change for control nontransduced neurons and GFP-neurons. In $\rho 1$-GFP-neurons, where the $\mathrm{GABA}_{\mathrm{C}}$ receptor number should be increasing with time since transduction, total current density increased, as expected. Pharmacological isolation of the $\mathrm{GABA}_{\mathrm{C}}$ component of the total current density (by bicuculline blockade of $\mathrm{GABA}_{\mathrm{A}}$ receptors) confirmed this time-dependent increase in the $\mathrm{GABA}_{\mathrm{C}}$ contribution (Fig. $6 \mathrm{~B}$, triangles). Interestingly, pharmacological isolation of the $\mathrm{GABA}_{\mathrm{A}}$ component (by I4AA blockade of $\mathrm{GABA}_{C}$ receptors) also showed a time-dependent increase in the current density (Fig. $6 B$, squares). In fact, the contribution of $\mathrm{GABA}_{\mathrm{A}}$ receptors to the increase in total current density was approximately equal to that of $\mathrm{GABA}_{\mathrm{C}}$ receptors. Again the presence of $\mathrm{GABA}_{\mathrm{C}}$ receptors seems to enhance $\mathrm{GABA}_{\mathrm{A}}$ receptor function.

It is possible that the apparent enhancement of $\mathrm{GABA}_{\mathrm{A}}$ receptor function is the result of the reduction in neuronal activity caused by transduction. It is well known that neuronal activity (Penschuck et al., 1999) or depolarization as a surrogate of neuronal activity (Gault and Siegel, 1997, 1998) regulates many neurotransmitter receptors, including the $\mathrm{GABA}_{\mathrm{A}}$ receptors. If the change in neuronal activity alone is responsible, then similar changes in activity in nontransduced neurons (by inhibition of electrical activity by TTX or suppression of synaptic transmission by elevated $\mathrm{Mg}^{2+}$ ) should mimic the action of $\rho_{1}$-GFP-virus. If the changes are nonspecific effects of viral transduction, the control GFP-virus should mimic the effects of the $\rho_{1}$-GFP-virus.

To preclude possible interactions between the chronic kynurenate $-\mathrm{Mg}^{2+}$ growth condition and the $\mathrm{GABA}_{\mathrm{A}}$ current density enhancement, the effects of TTX, $\mathrm{Mg}^{2+}$, and viral transduction were examined in neurons grown in otherwise normal culture medium. Neither culturing the neurons for $6 \mathrm{~d}$ in TTX or $\mathrm{Mg}^{2+}$-supplemented medium nor GFP-virus transduction increased the $\mathrm{GABA}_{\mathrm{A}}$ current density over that of control nontreated neurons (Fig. $6 C$ ). 
Table 1. Kinetic properties of GABA-evoked currents in hippocampal neurons

\begin{tabular}{|c|c|c|c|c|c|}
\hline Cell type & $\tau_{\text {act }}(\mathrm{msec})$ & $\tau_{\mathrm{des} 1}(\mathrm{msec})$ & $\tau_{\mathrm{des} 2}(\mathrm{msec})$ & $\tau_{\text {deact }}(\mathrm{msec})$ & $n$ \\
\hline Control & $41.5 \pm 3.6$ & $1056 \pm 126$ & $5639 \pm 623$ & $260.0 \pm 46.9$ & 10 \\
\hline $\operatorname{Ad}(\mathrm{GFP})$ & $37.6 \pm 3.6$ & $1470 \pm 185$ & $8888 \pm 1169$ & $209.5 \pm 17.1$ & 30 \\
\hline $\operatorname{Ad}(\rho 1 / \mathrm{GFP})+\mathrm{I} 4 \mathrm{AA}$ & $38.0 \pm 2.5$ & $1691 \pm 217$ & $8679 \pm 1496$ & $249.0 \pm 20.3$ & 17 \\
\hline $\operatorname{Ad}(\rho 1 /$ GFP $)+$ bicuc & $125 \pm 0.2^{a}$ & $7740 \pm 269^{a}$ & $13590 \pm 1240^{a}$ & $11600 \pm 1250^{a}$ & 35 \\
\hline
\end{tabular}

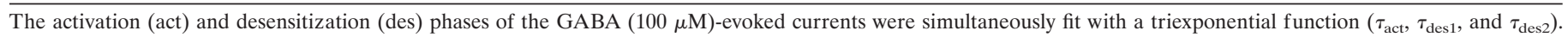

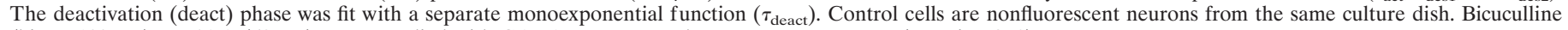
(bicuc; $100 \mu \mathrm{M})$ or I4AA $(50 \mu \mathrm{M})$ was coapplied with GABA to separate the current components (see Figs. 2, 3).

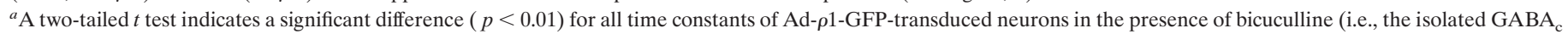
component). All time constants of the remaining three groups were indistinguishable.

\section{Ad- $\rho_{1}$-GFP transduction suppresses hyperexcitability- induced delayed neuronal death}

Prolonged unopposed excitation kills neurons (Abele et al., 1990; Murray et al., 1998). Regardless of the precise mechanism, because Ad- $\rho_{1}$-GFP transduction of hyperexcitable neurons decreases spontaneous activity, it may also decrease hyperexcitability-associated excitotoxic delayed neuronal death. To determine baseline excitotoxic neuronal death rates, we subjected hyperexcitable neurons to paroxysmal electrical activity by replacing the kynurenate- $\mathrm{Mg}^{2+}$ blocking medium with a medium without blockers for $30 \mathrm{~min}$ and then restoring the blocking medium. After $24 \mathrm{hr}, 45-52 \%$ of the neurons were dead, as determined by staining with ethidium homodimer. In control cultures subjected only to sham wash, with no period of paroxysmal activity, only $1-5 \%$ of the neurons were dead (Fig. $7 A$ ). Increasing the duration of hyperexcitability increased delayed neuronal death (Fig. $7 B$ ), consistent with a previous report (Murray et al., 1998). In three separate experiments, $2 \mathrm{~d}$ after transduction, hyperexcitable $\rho_{1}$ GFP-neurons were subjected to the same $30 \mathrm{~min}$ period of kynurenate $-\mathrm{Mg}^{2+}$ removal. After $24 \mathrm{hr}, 54 \pm 2 \%$ of the neurons were dead, not significantly different from baseline. However, of the $\sim 20 \%$ of neurons exhibiting GFP fluorescence and that are thus certain to have been successfully transduced and to express the $\mathrm{GABA}_{\mathrm{C}}$ receptor, only $1-5 \%$ were dead (Fig. $7 C, D$ ). Successful transduction with Ad- $\rho_{1}$-GFP provides nearly complete protection from hyperexcitability-induced excitotoxic delayed neuronal death in this model.

\section{DISCUSSION}

A recombinant adenovirus, Ad- $\rho_{1}$-GFP, designed to express both the GABA $\rho_{1}$ subunit and GFP was created. The coexpression of GFP allowed for an easy visual identification of successfully transduced neurons. Immunocytochemical study of individual GFP-positive neurons and a Western blot of virally transduced HEK293 cells demonstrated the de novo expression of $\rho_{1}$ protein. The punctate pattern of the membrane immunoreactivity could not be discerned, but because hippocampal neurons abundantly express the microtubule-associated protein-1B (MAP-1B) (data not shown), aggregation into receptor patches is expected (Hanley et al., 1999). The distinctive pharmacology of $\mathrm{GABA}_{\mathrm{C}}$ receptors (insensitive to bicuculline, sensitive to picrotoxin, selectively activated by CACA, and selectively inhibited by I4AA) allowed for a definitive confirmation of the presence of this receptor in Ad- $\rho_{1}$-GFP-transduced hippocampal neurons. As expected, $\rho_{1^{-}}$ GFP-neurons demonstrated CACA-activated chloride-permeable channels with the threefold slower activation and fivefold slower deactivation kinetics of functional $\mathrm{GABA}_{\mathrm{C}}$ receptors. Of note is our preliminary observation indicating a lack of bicucullineresistant mIPSC in $\rho_{1}$-GFP-neurons (Cheng and Yang, 2000).
Although we are unable to distinguish between the lack of functional versus physical presence of synaptic $\mathrm{GABA}_{\mathrm{C}}$ receptors, data thus far are consistent with the expression of abundant somatic but not synaptic $\mathrm{GABA}_{\mathrm{C}}$ receptors.

Although previous studies have suggested the presence of a bicuculline-resistant $\mathrm{GABA}_{\mathrm{C}}$-like receptor in the hippocampus during the first 2 weeks of postnatal development (Strata and Cherubini, 1994) and $\rho_{2}$ subunit mRNA has been detected in postnatal day 5 and adult rat hippocampus by Northern blot and reverse transcription-PCR analyses (Boue-Grabot et al., 1998), we observed no evidence of GABA-evoked current mediated by endogenous $\mathrm{GABA}_{\mathrm{C}}$ receptors in control neurons. In contrast to previous reports of no desensitization of $\rho_{1}$ subunits expressed in Xenopus oocytes (Cutting et al., 1991), our $\rho_{1}$-GFP-neurons exhibited slow but significant desensitization during GABA application. Significant desensitization of the $\mathrm{GABA}_{\mathrm{C}}$ receptors has also been seen when the human $\rho_{1}$ subunit is expressed in eukaryotic hosts (Filippova et al., 1999). These observations suggest a difference in processing of the receptor protein between the eukaryotic and the Xenopus expression systems. However, within the limitation of the rather slow perfusion used by us, the $\mathrm{GABA}_{C}$ receptors expressed in hippocampal neurons retain the fundamental pharmacological and kinetic properties of $\mathrm{GABA}_{\mathrm{C}}$ receptors that have been well described previously.

In neurons rendered hyperexcitable by chronic kynurenate$\mathrm{Mg}^{2+}$ treatment, Ad- $\rho_{1}$-GFP transduction dramatically altered the action potential firing pattern and reduced the frequency of spontaneous action potentials. The bursting pattern of paroxysmal action potential firing disappeared, and the overall action potential rate decreased to control levels. Application of CACA caused a hyperpolarizing shift in membrane potential, confirming the expression of $\mathrm{GABA}_{\mathrm{C}}$ receptors in these cells. Because forced expression of $\mathrm{GABA}_{\mathrm{C}}$ receptors abolished the hyperexcitability, we expected selective blockade of the $\mathrm{GABA}_{\mathrm{C}}$ receptors by I4AA to return the neurons to the hyperexcitable state. Surprisingly, I4AA alone had little effect on the spontaneous action potential rate. Bicuculline blockade of endogenous $\mathrm{GABA}_{\mathrm{A}}$ receptors in these same neurons also did not reestablish the hyperexcitable state. A technical reason for failure of the selective antagonists to reestablish hyperexcitability is unlikely. Although a high concentration of GABA could compete off the competitive antagonists, the proper summation of pharmacologically separated component currents equals the total current density (Fig. 6), indicating that under our experimental conditions, both bicuculline and I4AA completely blocked their respective receptors. Blockade of both $\mathrm{GABA}_{\mathrm{C}}$ and $\mathrm{GABA}_{\mathrm{A}}$ receptors by coapplication of both selective antagonists or application of picrotoxin alone was able to render the neurons once again hyperexcitable, but even these neurons 


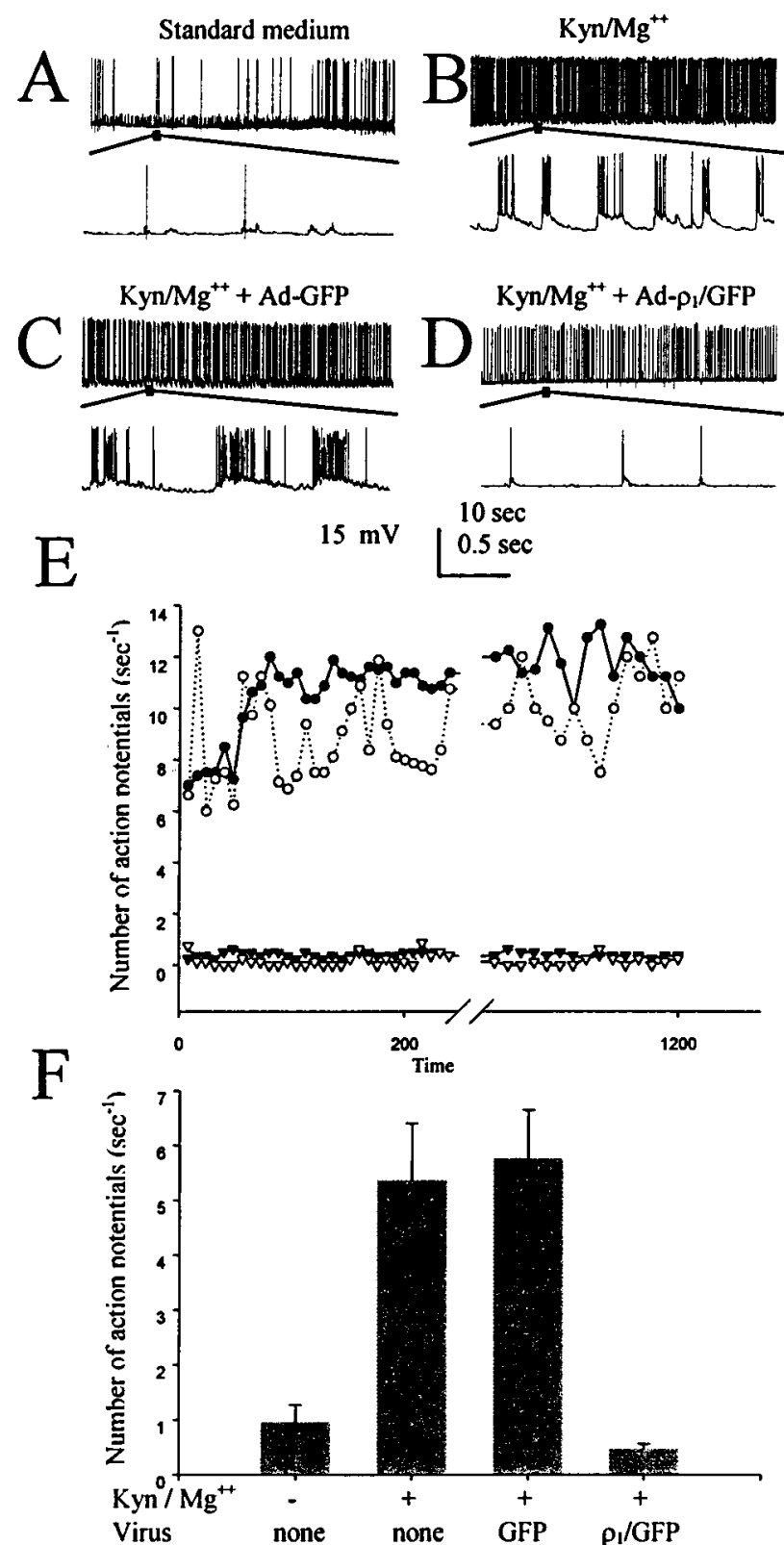

Figure 4. Expression of $\rho_{1}$ subunit suppresses spontaneous action potentials in the kynurenate- $\mathrm{Mg}^{2+}$ model of hyperexcitable neurons. $A, \mathrm{~A}$ representative whole-cell current-clamp recording from a hippocampal neuron grown under standard cell culture conditions. The bottom trace is an expanded view of the region denoted by the black bar. $B-D$, Neurons rendered hyperexcitable by kynurenate $-\mathrm{Mg}^{2+}$ treatment $(B)$ and transduction with Ad-GFP $(C)$ or Ad- $\rho_{1}-\operatorname{GFP}(D)$. $E$, Action potential firing rate for the same cells shown above demonstrating the stability of excitability over time (nontransduced hyperexcitable neurons, black circles; Ad-GFP-neurons, white circles; Ad- $\rho_{1}$-GFP-neurons, black inverted triangles; and control nontreated, nontransduced neurons, white inverted triangles). F, A bar graph of average action potential frequency for the four conditions $(n=8-20$ neurons for each). Kyn, Kynurenate.

had a lower frequency of spontaneous action potentials than did nontransduced or control Ad-GFP-transduced cells. These observations suggest that suppression of hyperexcitability by $\mathrm{Ad}-\rho_{1}$ GFP is not caused solely by the expression of additional inhibitory receptors but depends, at least in part, on other, unknown, alterations in neuronal excitability.

Neuronal hyperexcitability in the chronic kynurenate- $\mathrm{Mg}^{2+}$
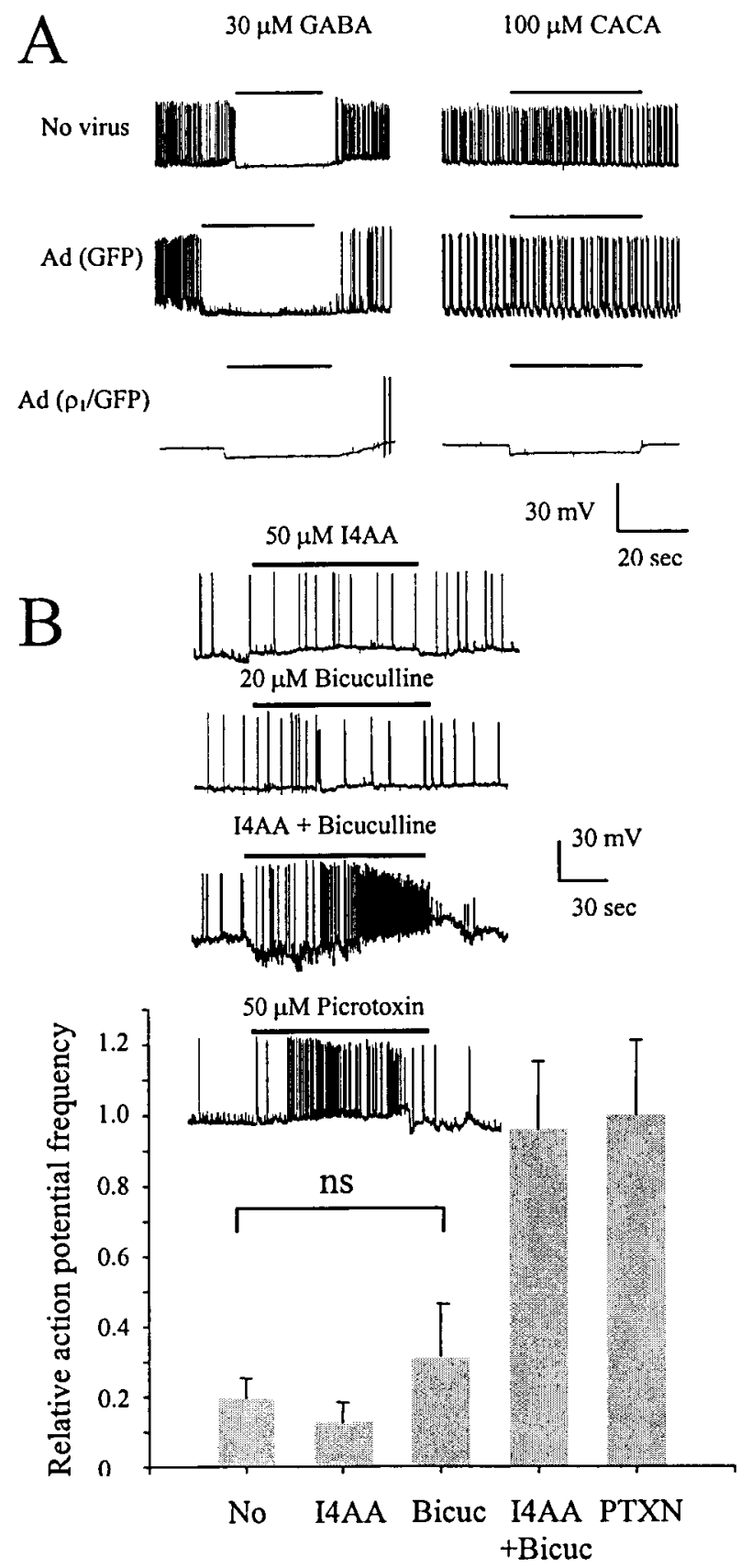

Figure 5. Pharmacological properties of hyperexcitable hippocampal neurons. $A$, Whole-cell current-clamp recordings from control nontransduced neurons (top), Ad-GFP-neurons (middle), or Ad- $\rho_{1}$-GFP-neurons (bottom) exposed to GABA (left) or CACA (right) are shown. Black horizontal lines denote the duration of drug application. $B, \mathrm{GABA}_{\mathrm{C}}$

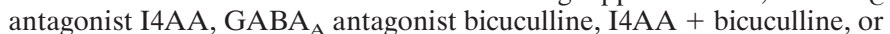
the nonspecific GABA antagonist picrotoxin were applied to Ad- $\rho_{1}$-GFPtransduced kynurenate $-\mathrm{Mg}^{2+}$-treated neurons. A summary bar diagram (bottom) of the relative action potential frequency during GABA antagonist applications ( $n=6-12$ neurons for each) is shown. No statistically significant difference $(n s, p>0.05)$ was found except for I4AA + Bicuc and picrotoxin $(P T X N)$.

model is caused by enhancement of both NMDA and AMPA/ kainate glutamate receptors (Van den pol et al., 1996). This mechanism is consistent with the recently demonstrated activitydependent decrease in membrane targeting of the AMPA receptor GluR1subunit (Lissen et al., 1998). Similarly, blocking neu- 


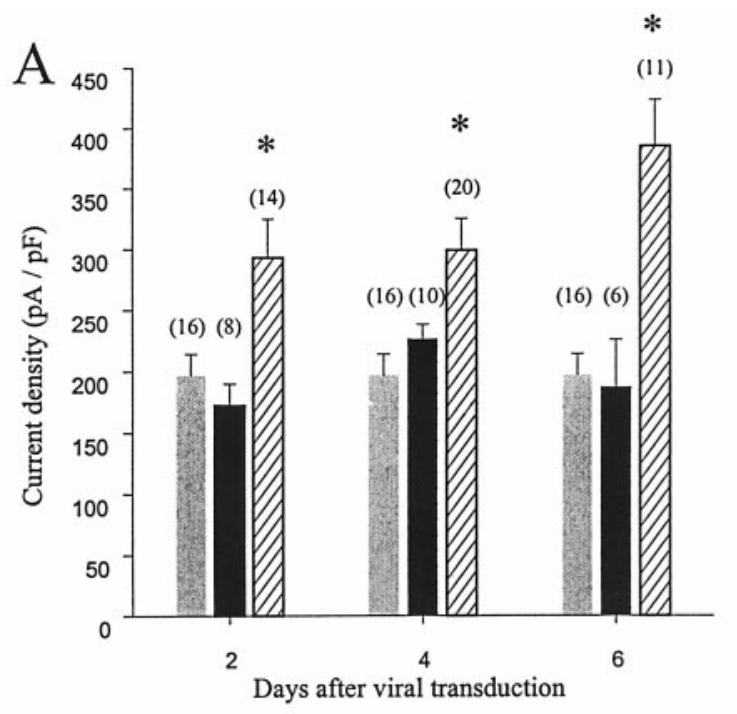

B

(10)
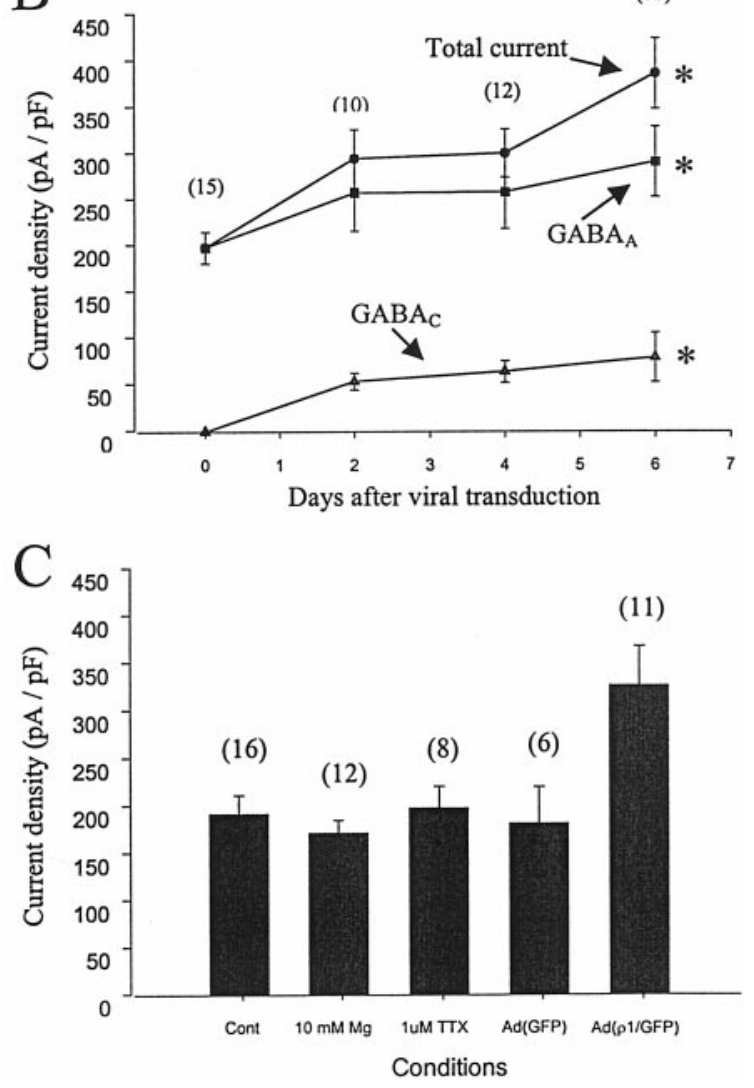

Figure 6. $\mathrm{GABA}_{\mathrm{A}}$ receptor-mediated current density is enhanced after transduction with the $\rho 1$-GFP virus. $A$, Current density (peak current evoked by $100 \mu \mathrm{M} \mathrm{GABA} /$ cell input capacitance) at 2, 4, and $6 \mathrm{~d}$ after transduction with no virus (gray bars), Ad-GFP (black bars), or Ad- $\rho 1$ GFP (hatched bars). An asterisk denotes statistical significance (Ad- $\rho 1-$ GFP vs no virus) at $p<0.02,0.01$, or 0.0001 for 2,4 , or $6 \mathrm{~d}$, respectively. Ad-GFP versus no virus was not significantly different at any time points $(p>0.21) . B$, Pharmacological separation of the total current (circle) into $\mathrm{GABA}_{\mathrm{A}}$ (square) and $\mathrm{GABA}_{\mathrm{C}}$ (triangle) components at different time points after viral transduction. At the day 6 time point (asterisks), both GABA $_{\mathrm{A}}(p<0.01)$ and $\mathrm{GABA}_{\mathrm{C}}(p<0.0001)$ components were significantly greater compared with those on day $0 . C$, Current density of neurons grown for $6 \mathrm{~d}$ in the control medium (Cont) supplemented as noted. Only Ad- $\rho 1$-GFP-transduced neurons demonstrated significantly greater current density $(p<0.001)$. For $A-C$, the numbers of cells are denoted in parentheses. ronal electrical activity by TTX results in elongation of dendritic spines (Papa and Segal, 1996) and a decrease in $\mathrm{GABA}_{\mathrm{A}} \alpha_{1}$ and $\alpha_{2}$ subunit density (Penschuck et al., 1999). Chronic activation of the $\mathrm{GABA}_{\mathrm{C}}$ receptor, which clamps the membrane potential to the chloride equilibrium potential, would be expected to result in the loss of electrical activity. By following this logic, the resulting electrical silence would upregulate AMPA receptors and downregulate $\mathrm{GABA}_{\mathrm{A}}$ receptors, increasing network excitability. This is the opposite of what we observed. Moreover, because the effect of chronic kynurenate- $\mathrm{Mg}^{2+}$ blockade is virtually to abolish spontaneous electrical activity, activation of $\mathrm{GABA}_{\mathrm{C}}$ receptors could have little additional effect on electrical activity in this culture system. An interesting possibility is that under our culture condition, stimulation of the $\mathrm{GABA}_{\mathrm{C}}$ receptors resulted in membrane depolarization overcoming the glutamate blockade. If this were the case, enhanced electrical activity could have resulted in the upregulation of $\mathrm{GABA}_{\mathrm{A}}$ receptors.

In Ad- $\rho 1-G F P$ neurons cultured in standard medium, pharmacological separation of the total current evoked by GABA into components mediated by the $\mathrm{GABA}_{\mathrm{A}}$ and the $\mathrm{GABA}_{\mathrm{C}}$ receptors demonstrated an unexpected induction of $\mathrm{GABA}_{\mathrm{A}}$ receptormediated current density. Although it is possible that this effect is simply the result of reduced neuronal activity caused by expression of $\mathrm{GABA}_{\mathrm{C}}$ receptors, neither inhibition of electrical activity (by TTX) nor inhibition of synaptic transmission (by elevated $\mathrm{Mg}^{2+}$ ) was sufficient to enhance current density (Fig. 6C). Additionally, electrical silence has been reported to reduce $\mathrm{GABA}_{\mathrm{A}}$ receptor $\alpha_{1}$ and $\alpha_{2}$ subunit expression when examined by in situ hybridization (Penschuck et al., 1999), and excessive depolarization (by elevated $\mathrm{K}^{+}$or glutamate stimulation of cerebellar granule neurons) increases $\mathrm{GABA}_{\mathrm{A}} \delta$ subunit transcription (Gault and Siegel, 1997, 1998). Both of these effects are in the wrong direction and fail to account for our observations. Induction of $\mathrm{GABA}_{\mathrm{A}}$ receptors by Ad- $\rho 1-\mathrm{GFP}$ must be mediated by signals other than membrane potential.

A recent study indicates that Ig-neuregulin, a member of the epidermal growth factor superfamily that activates receptor tyrosine kinase, selectively increases $\mathrm{GABA}_{\mathrm{A}}$ receptor expression via induction of the $\beta_{2}$ subunit (Rieff et al., 1999). Insulin, another growth factor well known to activate receptor tyrosine kinase, rapidly recruits $\mathrm{GABA}_{\mathrm{A}}$ receptors from the cytoplasmic to postsynaptic domains, increasing the amplitude of $\mathrm{GABA}_{\mathrm{A}}$ receptor-mediated mIPSC (Wan et al., 1997). It is possible that $\mathrm{GABA}_{\mathrm{C}}$ receptor expression-mediated induction of $\mathrm{GABA}_{\mathrm{A}}$ receptors involves this or similar intracellular signal transduction pathways. $\mathrm{GABA}_{\mathrm{C}}$ receptor-dependent post-translational modification of $\mathrm{GABA}_{\mathrm{A}}$ receptors is another possible mechanism for this effect.

Regardless of the precise mechanism, Ad- $\rho_{1}$-GFP reversed neuronal hyperexcitability and resulted in a reduction in delayed excitotoxic neuronal death. Our results are consistent with a previous observation that GABAergic neocortical neurons are resistant to NMDA receptor-mediated injury (Tecoma and Choi, 1989). Exogenous administration of diazepam, an allosteric GABA potentiator, also has been shown to reduce postischemic and traumatic neuronal death in vivo (Schwartz et al., 1995; O'Dell et al., 2000). Because generalized augmentation of GABAergic inhibition, whether pharmacologically or by gene targeting, may impair normal synaptic plasticity (Levkovitz et al., 1999), there may be a strong advantage for a regional rather than a general enhancement of inhibition. Delivery of adenovirus through direct stereotactic injection might allow expression of 


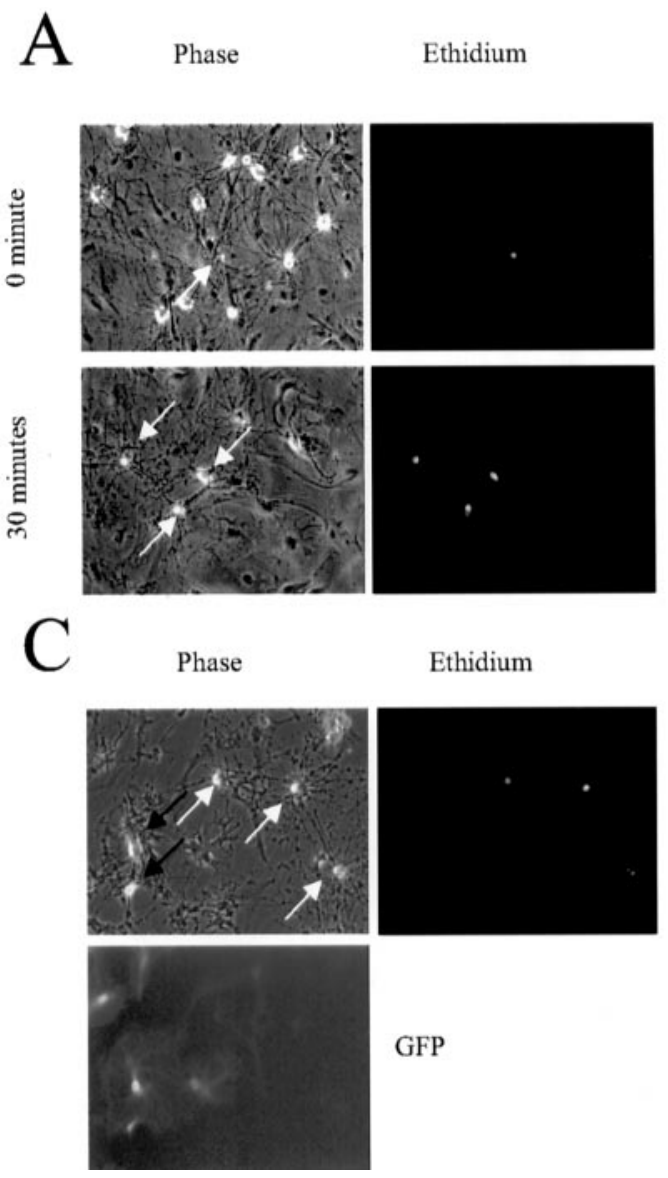

B
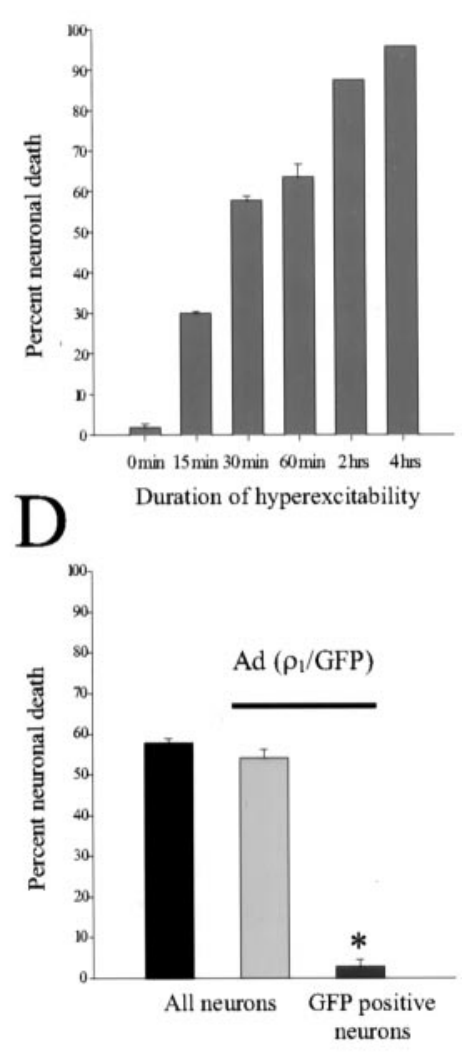

Figure 7. Suppression of hyperexcitability-induced delayed neuronal death. $A$, Phase-contrast and fluorescent image pairs of a culture dish rendered hyperexcitable for $0 \mathrm{~min}$ (top) or $30 \mathrm{~min}$ (bottom). Arrows point to the ethidium-homodimer-positive dead neurons. $B$, Summary bar diagram of the percentage of neuronal death versus the duration of hyperexcitability. $C$, Phase-contrast (top left), GFP (bottom), and ethidium (top right) images from an Ad- $\rho_{1}$-GFP-transduced culture subjected to $30 \mathrm{~min}$ of hyperexcitability. White arrows point to nontransduced dead (i.e., GFP-negative and ethidiumpositive) neurons, and black arrows point to transduced live (i.e., GFP-positive and ethidiumnegative) neurons. $D$, Summary bar diagram of delayed neuronal death in control and Ad- $\rho_{1}$-GFPtransduced neurons from three separate experiments (asterisk, significant at $p<0.0001$ ). virally transduced $\mathrm{GABA}_{\mathrm{C}}$ receptors in a sharply restricted subset of neurons, augmenting endogenous GABA receptormediated neuroprotection without the side effects of conventional drug therapy.

We focused on a forced expression of inhibitory GABA receptors to suppress hyperexcitability, but other mechanisms could be used. For example, increased GABAergic inhibition by enhancement of presynaptic release in transgenic mice overexpressing superoxide results in resistance to systemic kainic acid-induced seizures (Levkovitz et al., 1999). Overexpression of a chloride transporter, forcing the chloride reversal potential to become more negative (Staley et al., 1996), is another approach. Excitability can be reduced by viral expression of inwardly rectifying potassium channels with a consequent increase in the threshold for action potential generation (Ehrengruber et al., 1997; Johns et al., 1999). Because activation of the classical MAP kinases (Murray et al., 1998) may mediate delayed neuronal death, expression of a dominant-negative MAP kinase mutant might render neurons resistant to excitotoxic death. Finally, a deeper understanding of the genetic basis of epilepsy could lead to a mechanismbased gene therapy. For example, defects in channel proteins such as GIRK2, GluRB, or Kv1.1 have been implicated as possible causes of epilepsy (Noebles, 1996). Targeted corrections of such defects might be possible in the future.

\section{REFERENCES}

Abele AE, Scholz KP, Scholz WK, Miller RJ (1990) Excitotoxicity induced by enhanced excitatory neurotransmission in cultured hippocampal pyramidal neurons. Neuron 2:413-419.

Amin J, Weiss DS (1994) Homomeric $\rho_{1}$ GABA channels: activation properties and domains. Receptors Channels 2:227-236.
Amin J, Weiss DS (1996) Insights into the activation mechanism of $\rho_{1}$ GABA receptors obtained by coexpression of wild type and activationimpaired subunits. Proc R Soc Lond B Biol Sci 263:273-282.

Bett AJ, Haddara W, Prevec L, Graham FL (1994) An efficient and flexible system for construction of adenovirus vectors with insertions or deletions in early regions 1 and 3. Proc Natl Acad Sci USA 91:8802-8806.

Bormann J (2000) The "ABC" of GABA receptors. Trends Pharmacol Sci 21:16-19.

Bormann J, Feigenspan A (1995) GABA $_{C}$ receptors. Trends Neurosci 18:515-519.

Boue-Grabot E, Roudbaraki M, Bascles L, Tramu G, Block B, Garret M (1998) Expression of GABA receptor $\rho$ subunits in rat brain. J Neurochem 70:899-907.

Cheng Q, Yang J (2000) Subsynaptic targeting of adenovirus-transduced $\mathrm{GABA}_{\mathrm{A}}$ but not $\mathrm{GABA}_{\mathrm{C}}$ receptor subunits in hippocampal neurons. Soc Neurosci Abstr 26:1656.

Cutting GR, Lu L, O'Hara BF, Kasch LM, Montrose-Rafizadeh C, Donovan DM, Shimada S, Antonarakis SE, Guggino WB, Uhl GR, Kazazian Jr HH (1991) Cloning of the $\gamma$-aminobutyric acid (GABA) $\rho_{1}$ cDNA: a GABA receptor subunit highly expressed in the retina. Proc Natl Acad Sci USA 88:2673-2677.

Ehrengruber MU, Doupnik CA, Xu Y, Garvey J, Jasek MC, Lester HA, Davidson N (1997) Activation of heteromeric G protein-gated inward rectifier $\mathrm{K}$ channel over-expressed by adenovirus gene transfer inhibits the excitability of hippocampal neurons. Proc Natl Acad Sci USA 94:7070-7095.

Enz R, Cutting GR (1999) GABAC receptor $\rho$ subunits are heterogeneously expressed in the human CNS and form homo- and heterooligomers with distinct properties. Eur J Neurosci 11:41-50.

Filippova N, Dudley R, Weiss DS (1999) Evidence for phosphorylationdependent internalization of recombinant human $\rho_{1} \mathrm{GABA}_{\mathrm{C}}$ receptors. J Physiol (Lond) 518:385-399.

Friedman LK, Pellegrini-Giampietro DE, Sperber EF, Bennet MV, Moshe SL, Zukin RS (1994) Kainate-induced status epilepticus alters glutamate and $\mathrm{GABA}_{\mathrm{A}}$ receptor gene expression in adult rat hippocampus: an in situ hybridization study. J Neurosci 14:2697-2707.

Furshpan EJ, Potter DD (1989) Seizure-like activity and cellular damage in rat hippocampal neurons in cell culture. Neuron 3:199-207.

Gault LM, Siegel RE (1997) Expression of the $\mathrm{GABA}_{\mathrm{A}}$ receptor $\delta$ 
subunit is selectively modulated by depolarization in cultured rat cerebellar granule neurons. J Neurosci 17:2391-2399.

Gault LM, Siegel RE (1998) NMDA receptor stimulation selectively initiates GABAA receptor delta subunit mRNA expression in cultured rat cerebellar granule neurons. J Neurochem 70:1907-1915.

Gibbs JW, Sombati S, Delorenzo RJ, Coulter DA (1997) Physiological and pharmacological alterations in postsynaptic $\mathrm{GABA}_{\mathrm{A}}$ receptor function in a hippocampal culture model of chronic spontaneous seizures. J Neurophysiol 77:2139-2152.

Griesbeck O, Korte M, Gravel C, Bonhoeffer T, Thoenen H (1997) Rapid gene transfer into cultured hippocampal neurons and acute hippocampal slice using adenoviral vectors. Mol Brain Res 44:171-177.

Hackam AS, Wang TL, Guggino WB, Cutting GR (1997) The $\mathrm{N}$-terminal domain of human GABA receptor $\rho_{1}$ subunits contains signals for homoligomeric and heteroligomeric interaction. J Biol Chem 272:13750-13757.

Hackam AS, Wang TL, Guggino WB, Cutting GR (1998) Sequences in the amino termini of GABA $\rho$ and GABA $_{A}$ subunits specify their selective interaction in vitro. J Neurochem 70:40-46.

Hanley JG, Koulen P, Bedford F, Gordon-Weeks PR, Moss SJ (1999) The protein MAP-1B links $\mathrm{GABA}_{\mathrm{C}}$ receptors to the cytoskeleton at retinal synapses. Nature 397:66-69.

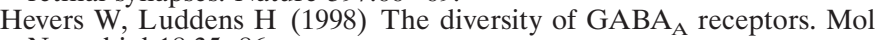
Neurobiol 18:35-86.

Jallon P (1997) The problem of intractability: the continuing need for new medical therapies in epilepsy. Epilepsia 38:S37-S42.

Johns DC, Marx R, Mains RE, O'Rourke B, Marban E (1999) Inducible genetic suppression of neuronal excitability. J Neurosci 19:1691-1697.

Jones MV, Sahara Y, Dzubay JA, Westbrook GL (1998) Defining affinity with the $\mathrm{GABA}_{\mathrm{A}}$ receptor. J Neurosci 18:8590-8604.

Levkovitz Y, Avignone E, Groner Y, Segal M (1999) Upregulation of GABA neurotransmission suppresses hippocampal excitability and prevents long-term potentiation in transgenic superoxide dismutaseoverexpressing mice. J Neurosci 19:10977-10984.

Lissen DV, Gomperts SN, Carroll RC, Christine CW, Kalman D, Kitamura M, Hardy S, Nicoll RA, Malenka RC, Zastrow MV (1998) Activity differentially regulates the surface expression of synaptic AMPA and NMDA glutamate receptors. Proc Natl Acad Sci USA 95:7097-7102.

Loscher W (1998) New vision in the pharmacology of anticonvulsants. Eur J Pharmacol 342:1-13.

Mody I (1998) Ion channels in epilepsy. Annu Rev Pharmacol Toxicol 38:321-350.

Murray B, Alessandrini A, Cole AJ, Yee AG, Furshpan EJ (1998) Inhibition of the p44/42 MAP kinase pathway protects hippocampal neurons in a cell-culture model of seizure activity. Proc Natl Acad Sci USA 95:11975-11980.

Noebles JL (1996) Targeting epilepsy genes. Neuron 16:241-244.

O’Dell DM, Gibson CH, Wilson MS, DeFord SM, Hamm RJ (2000)
Positive and negative modulation of the $\mathrm{GABA}_{\mathrm{A}}$ receptor and outcome after traumatic brain injury in rats. Brain Res 861:325-332.

Papa M, Segal M (1996) Morphological plasticity in dendritic spines of cultured hippocampal neurons. Neuroscience 71:1005-1011.

Penschuck S, Paysan J, Giorgetta O, Fritschy JM (1999) Activitydependent regulation of $\mathrm{GABA}_{\mathrm{A}}$ receptors. Ann NY Acad Sci 868:654-666.

Rice A, Rafiq A, Shapiro SM, Jakoi ER, Coulter DA, DeLorenzo RJ (1996) Long-lasting reduction of inhibitory function and $\gamma$-aminobutyric acid type A receptor subunit mRNA expression in a model of temporal lobe epilepsy. Proc Natl Acad Sci USA 93:9665-9669.

Rieff HI, Raetzman LT, Sapp DW, Yeh HH, Siegel RE, Corfas G (1999) Neuregulin induces $\mathrm{GABA}_{\mathrm{A}}$ receptor subunit expression and neurite outgrowth in cerebellar granule cells. J Neurosci 19:10757-10766.

Schwartz RD, Yu X, Katzman MR, Haydon-Hixson DM, Perry JM (1995) Diazepam, given postischemia, protects selectively vulnerable neurons in the rat hippocampus and striatum. J Neurosci 15:529-539.

Shimada S, Cutting G, Uhl GR (1992) $\gamma$-Aminobutyric acid A or C receptor? $\gamma$-Aminobutyric acid $\rho_{1}$ receptor RNA induces bicuculline-, barbiturate-, and benzodiazepine-insensitive $\gamma$-aminobutyric acid responses in Xenopus oocytes. Mol Pharmacol 41:683-687.

Smith GM, Berry RL, Yang J, Tanelian D (1997) Electrophysiological analysis of dorsal root ganglion neurons pre- and post-coexpression of green fluorescent protein and functional 5-HT3 receptor. J Neurophysiol 77:3115-3121.

Staley K, Smith R, Schaak J, Wilcox C, Jentsch TJ (1996) Alteration of $\mathrm{GABA}_{\mathrm{A}}$ receptor following gene transfer of the CLC-2 chloride channel. Neuron 17:543-551.

Strata F, Cherubini E (1994) Transient expression of a novel type of GABA response in rat CA3 hippocampal neurones during development. J Physiol (Lond) 480:493-503.

Tecoma ES, Choi DW (1989) GABAergic neocortical neurons are resistant to NMDA receptor-mediated injury. Neurology 39:676-682.

Van den pol AN, Obrietan K, Belousov A (1996) Glutamate hyperexcitability and seizure-like activity throughout the brain and spinal cord upon relief from chronic glutamate receptor blockade in culture. Neuroscience 74:653-674.

Wan Q, Xiong ZG, Man HY, Ackerley CA, Braunton J, Lu WY, Becker LE, MacDonald JF, Want YT (1997) Recruitment of functional $\mathrm{GABA}_{\mathrm{A}}$ receptors to postsynaptic domains by insulin. Nature 686:686-690.

Wang TL, Guggino WB, Cutting GR (1994) A novel $\gamma$-aminobutyric acid receptor subunit $(\rho 2)$ cloned from human retina forms bicucullineinsensitive homooligomeric receptors in Xenopus oocytes. J Neurosci 14:6524-6531.

Wilkemeyer MF, Smith KL, Zarie MM, Benke TA, Swann JW, Angelides KJ, Eisensmith RC (1996) Adenovirus-mediated gene transfer into dissociated and explant cultures of rat hippocampal neurons. J Neurosci Res 43:161-174. 